УДК 622.276 .6

\title{
ИССЛЕДОВАНИЕ МЕТОДОВ ИНТЕНСИФИКАЦИИ ДОБЫЧИ НЕФТИ ИЗ НИЖНЕМЕЛОВЫХ ОТЛОЖЕНИЙ ГОРЯЧЕИСТОЧНЕНСКОГО МЕСТОРОЖДЕНИЯ
}

\author{
Бакраев Мубарик Мовлаевич1, \\ mubarik@yandex.ru
}

\author{
Булюкова Флюра Зиннатовна², \\ flura2003@mail.ru
}

\author{
Думлер Елена Борисовна², \\ dumler08@mail.ru
}

\section{Дельбиев Айнди Сайдиевич 1 , Ayndi.delbiev@mail.ru}

1 Грозненский государственный нефтяной технический университет им. академика М.Д. Миллионщикова, Россия, 364902, г. Грозный, пр. им. Х.А. Исаева, 100.

2 Уфимский государственный нефтяной технический университет, Россия, 450062, г. Уфра, ул. Космонавтов, 1.

\begin{abstract}
Актуальность. На современном этапе перед нефтедобывающей отраслью стоят серьезные задачи по поиску новых эффективных технологий для повышения нефртеотдачи пластов. В процессе разработки нижнемеловой залежи несрти наблюдается тенденция значительного снижения дебита скважин за счет отложений в насосно-компрессорных трубах труднорастворимых асфральтено-смолистых веществ. С падением дебита, давления и температуры интенсивность отложений, в том числе кольматирующих элементов в призабойной зоне пласта, увеличивалась. В статье решается задача подбора эфрфективного способа обработки призабойной зоны с целью повышения интенсификации добычи и увеличения нефтеотдачи пласта за счет более полной ее очистки от трудноудаляемых кольматирующих отложений.

Основной целью исследования является определение наиболее эфффективного способа обработки терригенных коллекторов нижнемеловых залежей для воздействия на скелет горной породы, образующей коллектор, и защиты от кольматирующих отложений.

Объект: Горячеисточненское месторождение, расположенное на восточном окончании Терского хребта Грозненского района Чеченской республики. Месторождение многопластовое. В разработке и эксплуатации пребывали миоценовая, верхнемеловая, альбская, альб-аптская и барремская залежи. Наиболее крупнье объекты связаны с верхнемеловыми и альб-аптскими отложениями нижнего мела. Миоценовая залежь практически выработана. Альбская и барремская залежи недоразведаны и эксплуатируются единичными скважинами. Продуктивные отложения альб-аптской залежи характеризуются сравнительно низкими коллекторскими свойствами.

Методы: исследование различных технологических методов воздействия на призабойную зону пласта скважины.

Результаты. С целью интенсификации добычи и увеличения нефтеодачи пласта предлагается производить обработку терригенных коллекторов нижнего мела органическими растворителями РИНГО-ГКС, РИНГО-СКС и МКС. Экспериментальные обработки в скважинах показали эфффективность воздействия на призабойную зону и полную её очистку от кольматирующих отложений.
\end{abstract}

\section{Ключевые слова:}

Интенсификация добычи нефтти, асфальтосмолистье парафинистье отложения, кольматирующие элементы, нижнемеловая залежь, призабойная зона пласта.

\section{Введение}

Горячеисточненское месторождение расположено на восточном окончании Терского хребта, в пятнадцати километрах к северу от города Грозный Грозненского района Чеченской республики. В процессе разработки нижнемеловой залежи нефти дебиты по скважинам изменялись в широком диапазоне - от 180 до 200 т/сут. Изменение дебита и устьевого давления происходило в основном за счет отложений в насосно-компрессорных трубах труднорастворимых асфальтено-смолистых веществ (АСВ). С падением дебита, устьевых давлений и температур интенсивность отложений увеличивалась. На современном этапе перед нефтедобывающей отраслью Чеченской респуб- лики стоят серьезные задачи по поиску новых эффективных технологий по повышению нефтеотдачи пластов $[1,2]$.

\section{Характеристика исследуемого объекта}

Многопластовое месторождение Горячеисточненское открыто в середине прошлого века. В разработке и пробной эксплуатации перебывали миоценовая, верхнемеловая, альб-аптская, альбская и барремская залежи нижнего мела. Наиболее крупные объекты связаны с верхнемеловыми и альб-аптскими отложениями нижнего мела. Миоценовая залежь практически выработана. Альбская и барремская залежи недоразведаны и эксплуатируются единичными скважинами. 
Из эксплуатационных объектов - залежей нефти, отобрано: альбский - 30,9 тыс. т нефти, жидкости 33,5 тыс. т и газа $-12,6$ млн Нм ${ }^{3}$, текущий коэффициент нефтеизвлечения составляет 0,281 , коэффициент использования извлекаемых запасов нефти $56,2 \%$; альб-аптский - 1072,0 тыс. т нефти, жидкости - 1209,0 тыс. т и газа - 406,3 млн Нм ${ }^{3}$, текущий коэффициент нефтеизвлечения составляет 0,143 , коэффициент использования извлекаемых запасов нефти - 28,7 \%; барремский - 42,7 тыс. т нефти, жидкости - 43,2 тыс. т и газа $-17,1$ млн $\mathrm{Hм}^{3}$, текущий коэффициент нефтеизвлечения составляет 0,063 , коэффициент использования извлекаемых запасов нефти - 12,6 \%. Распределение скважин по суммарной добыче нефти (рис. 1) нижнемеловой залежи представлено в табл. 1.

Начиная с 1994 г., в связи с военными событиями, была нарушена режимная эксплуатация скважин до полной их остановки. С 1994 по 2004 гг. весь фонд скважин практически бездействовал. За этот период разработки нижнемеловых залежей нефти систематические замеры пластового давления по скважинам не проводились. Малое количество замеров пластового давления залежи не позволяло проследить динамику его изменения во времени.

С 2002 г. начался период послевоенного восстановления нефтяной промышленности Чечни, и нижнемеловые залежи нефти были вновь введены в эксплуатацию. В связи с недостаточной информацией о характеристиках пласта и гидродинамической системы в целом динамика изменения пластового давления в залежи определяется расчетным путем с использованием уравнений В.Н. Щелкачева [3] и материального баланса расхода упругой энергии, а также фактических показателей по состоянию отбора жидкости и кратковременной закачки воды.

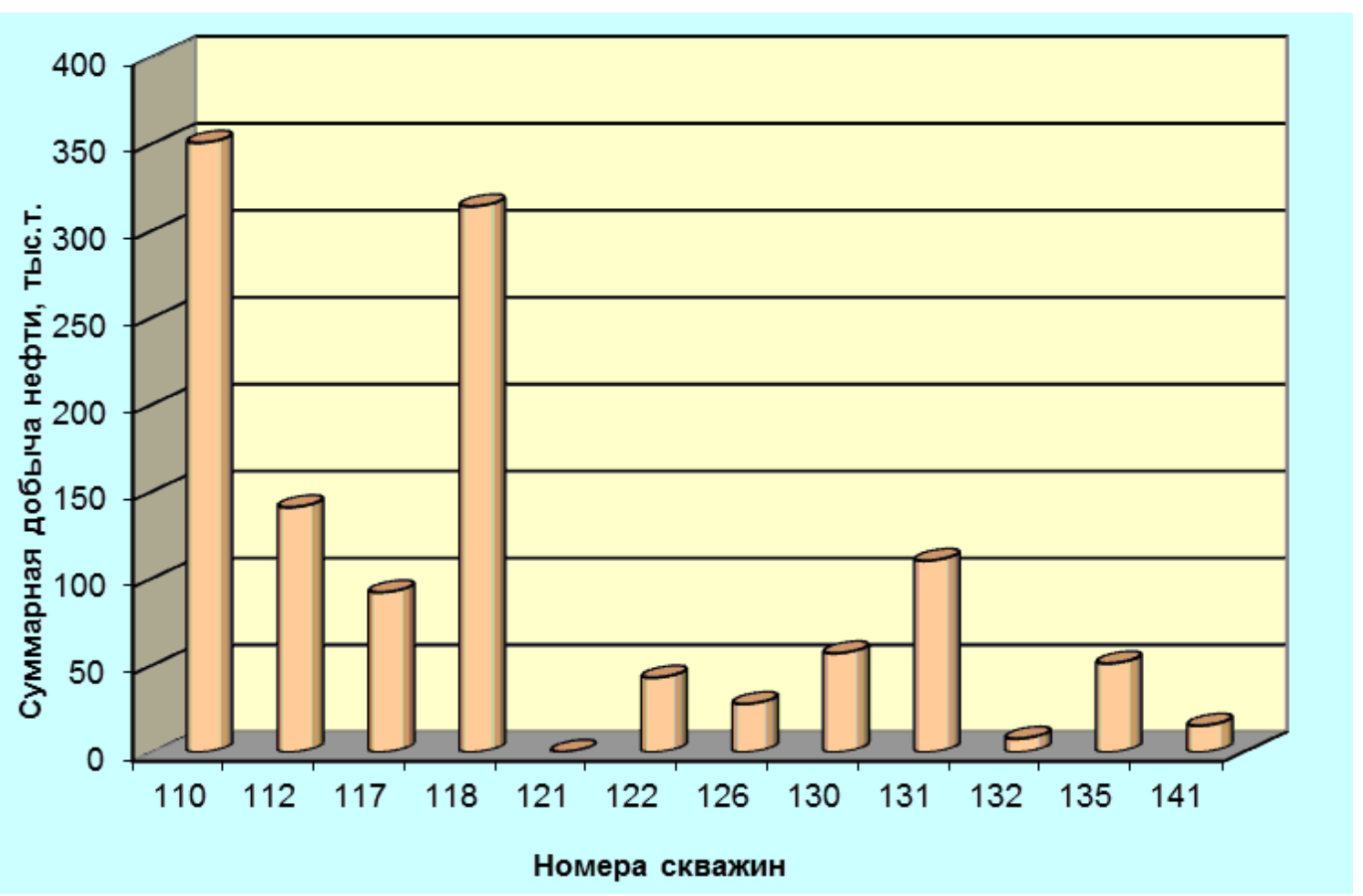

Pис. 1. Распределение скважин по суммарной добыче нефти нижнемеловой залежи нефти

Fig. 1. Distribution of wells by total oil production of the development of the Lower Cretaceous oil reservoir

Таблица 1. Распределение скважин по суммарной добыче нефти нижнемеловой залежи

Table 1. Distribution of wells by total oil production of the lower Cretaceous Deposit

\begin{tabular}{|c|c|c|c|}
\hline $\begin{array}{l}\text { Номер скважины } \\
\text { Well number }\end{array}$ & $\begin{array}{c}\text { Интервал дебита, } \mathrm{Q}_{\mathrm{H}} \text {, тыс. т } \\
\text { Debit interval, } \mathrm{Q}_{\mathrm{H}} \text {, thousand tons }\end{array}$ & $\begin{array}{c}\text { Кол-во скв., шт. } \\
\text { Number of wells, pcs. }\end{array}$ & $\begin{array}{c}\text { Дебит, } \mathrm{Q}_{\mathrm{H}}, \text { тыс. т } \\
\text { Debit, } \mathrm{Q}_{\mathrm{H}} \text {, thousand tons }\end{array}$ \\
\hline 122 & \multirow{3}{*}{$0-20$} & \multirow{3}{*}{3} & 0,20 \\
\hline 133 & & & 7,90 \\
\hline 142 & & & 15,30 \\
\hline 127 (альб.)/(alb.) & $20-40$ & 1 & 27,80 \\
\hline 123 & \multirow{3}{*}{$40-60$} & \multirow{3}{*}{3} & 42,90 \\
\hline 136 & & & 46,40 \\
\hline 131 (баррем.)/(barrem.) & & & 57,40 \\
\hline 118 & \multirow{2}{*}{$90-120$} & \multirow{2}{*}{2} & 92,00 \\
\hline 132 & & & 110,20 \\
\hline 113 (баррем.)/(barrem.) & $140-150$ & 1 & 140,90 \\
\hline 119 & \multirow{2}{*}{$300-350$} & \multirow{2}{*}{2} & 314,00 \\
\hline 111 & & & 350,60 \\
\hline
\end{tabular}


В процессе разведки и разработки нижнемеловых залежей нефти Горячеисточненского месторождения был проведен комплекс лабораторных, промысловых геофизических и гидродинамических исследований добывающих скважин и пластов [4]. Анализ геолого-геофизических и промысловых материалов показал, что нижнемеловая альб-аптская залежь по геологическому строению оказалась значительно более сложной, чем представлялась при подсчете запасов нефти 1992 г. и при проектировании разработки на 1993-1997 гг. Продуктивные отложения альб-аптской залежи характеризуются сравнительно низкими коллекторскими (фильтрационными) свойствами $[5,6]$. Проведенные исследования позволили установить динамику снижения пластового давления на этапах дренирования продуктивных отложений и динамику его восстановления из-за вынужденного прекращения разработки месторождения [7]. Динамика изменения расчетного пластового давления нефтяных залежей индивидуально по каждому эксплуатационному объекту нижнемеловых отложений приведена на рис. 2-4.

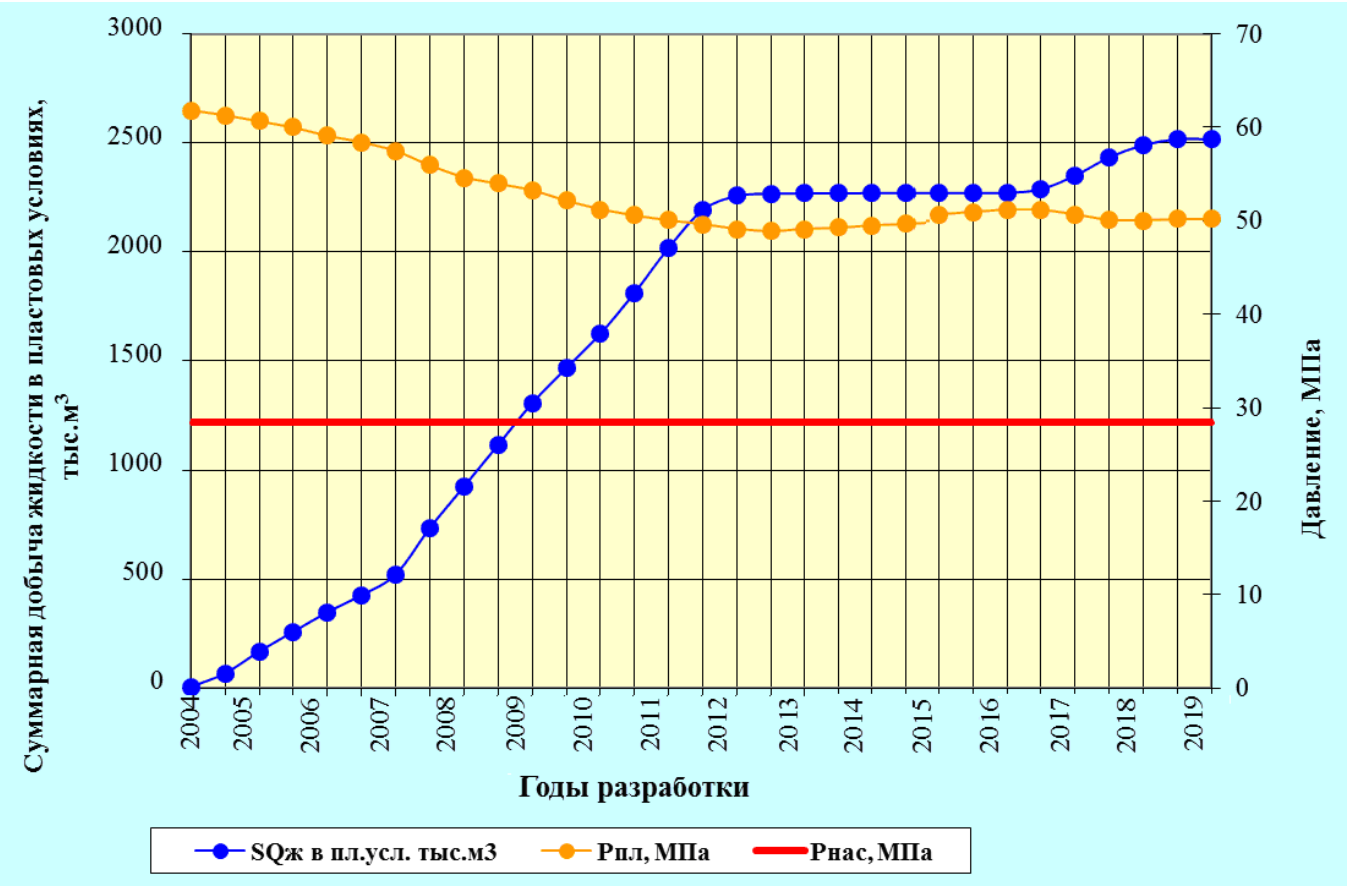

Pис. 2. Зависимости изменения пластового давления залежи нефти альб-аптских отложений

Fig. 2. Dependencies of the change in reservoir pressure of the oil accumulation of the Albian-Aptian deposits

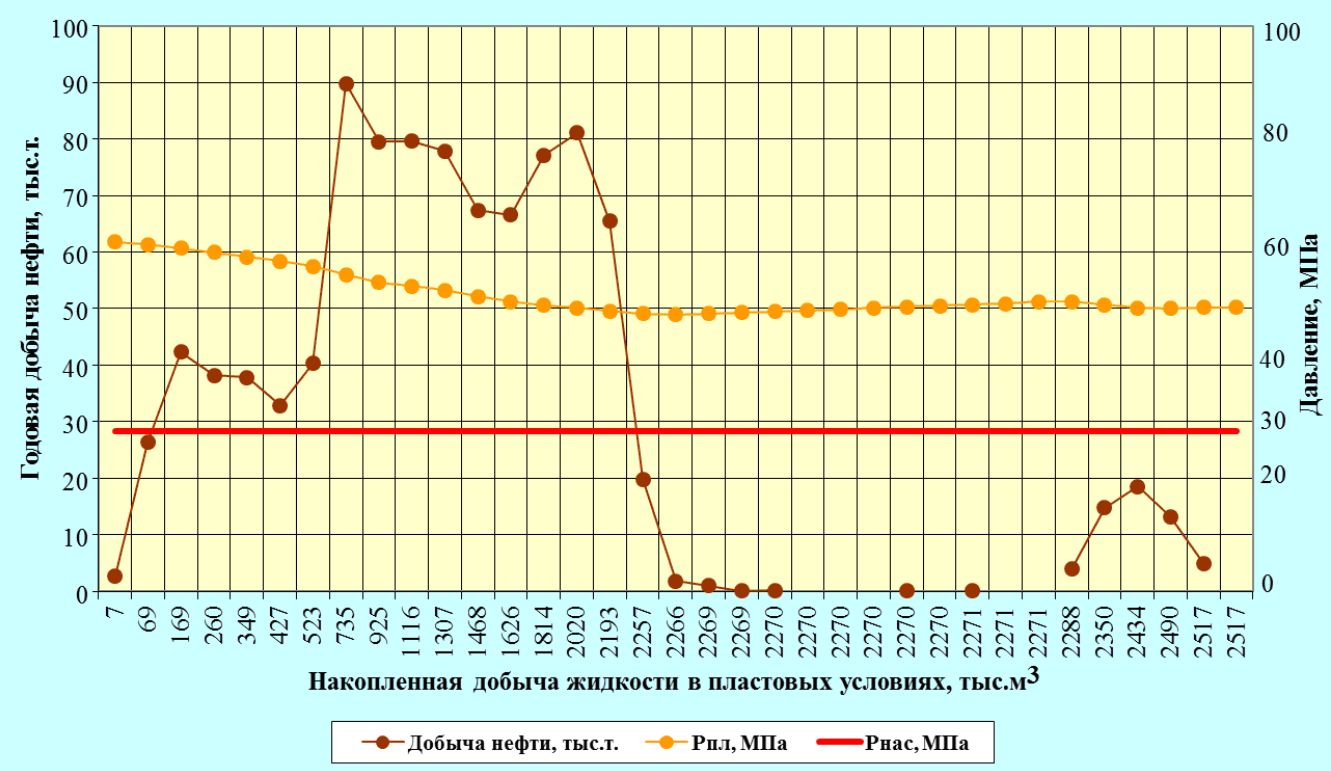

Рис. 3. Зависимости пластового давления залежи нефти альб-аптских отложений как функиии накопленной добычи жидкости

Fig. 3. Dependences of the pressure of the oil reservoir of the Albian-Aptian deposits as a function of the cumulative fluid production 


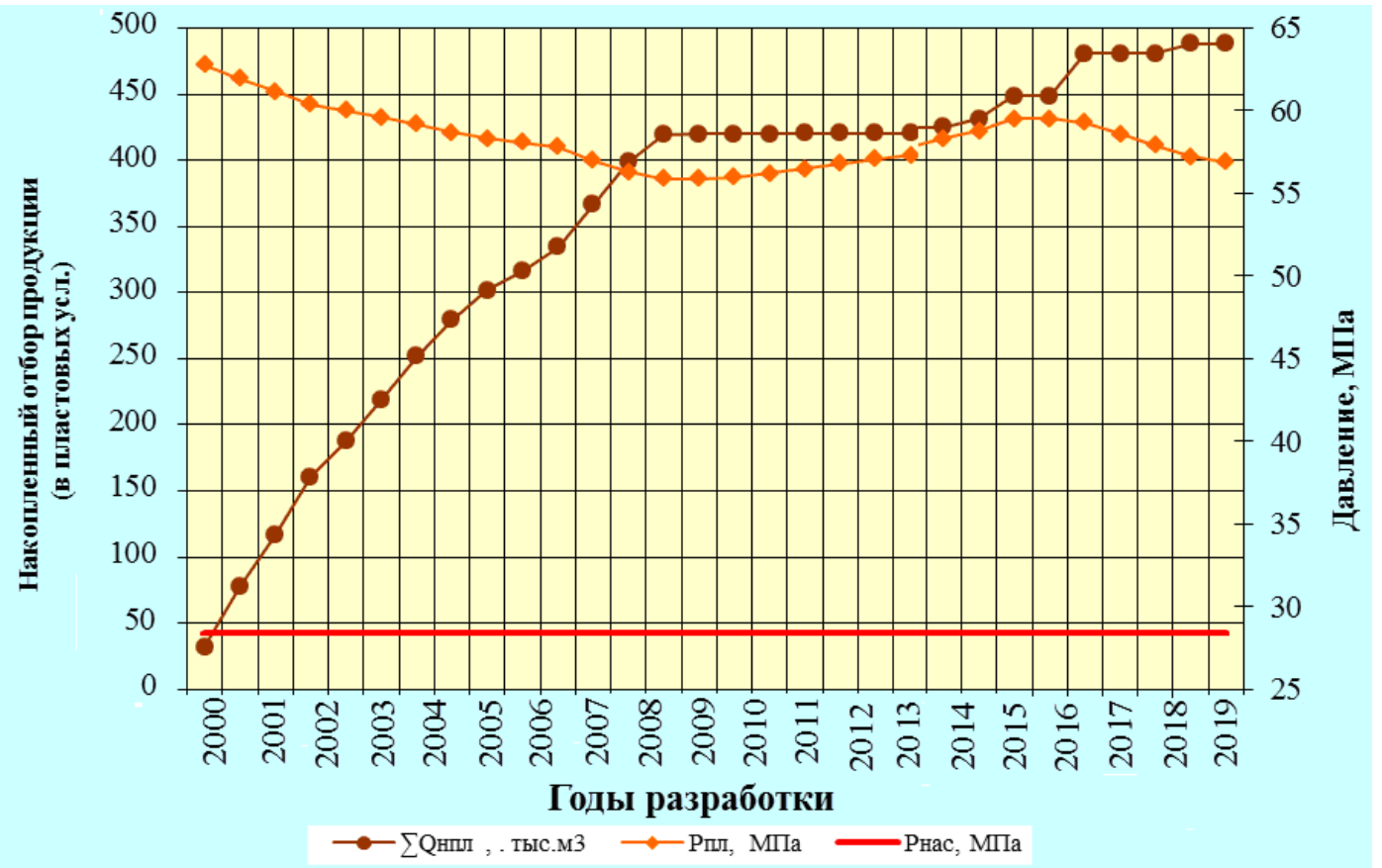

Pис. 4. Зависимости изменения давления пластов залежи нефти барремских отложений

Fig. 4. Dependences of pressure changes in oil reservoirs of the Barremian deposits

Исследования показали, что пластовое давление оценивается следующим образом: по альб-аптской залежи - 50,2 МПа на отметке минус 4700 м, по барремской залежи - 57,0 МПа на отметке минус 4800 м. Таким образом, на текущий момент времени по эксплуатационным объектам имеется следующий запас упругой энергии пластовой системы над давлением насыщения нефти газом: по альб-аптской - 21,8 МПа, барремской - 28,5 МПа.

Нефть альбских отложений относится к легким (плотность $815 \mathrm{\kappa r} / \mathrm{M}^{3}$ ), малосмолистым (содержание силикагелевых смол $2,60 \%$; асфальтенов $0,17 \%$ мас.), малосернистым (содержание серы 0,08 \%), парафинистым (парафина 2,3 \% мас.) (табл. 2).

Таблица 2. Характеристика условий залегания и физико-химические свойства нефти

Table 2. Characteristics of oil occurrence conditions and physical and chemical properties

\begin{tabular}{|c|c|c|c|}
\hline \multirow{2}{*}{$\begin{array}{c}\text { Показатели } \\
\text { Indicators }\end{array}$} & \multicolumn{3}{|c|}{ Нижнемеловые залежи нефти/Lower Cretaceous oil deposits } \\
\hline & Альбские/Albian & Альб-аптские/Albian-Aptian & Барремские/Barremian \\
\hline $\begin{array}{l}\text { Плотность нефти в пластовых условиях, кг/м }{ }^{3} \\
\text { Oil density in reservoir conditions, } \mathrm{kg} / \mathrm{m}^{3}\end{array}$ & 576 & 596 & $\begin{array}{c}\text { нет данных } \\
\text { no data }\end{array}$ \\
\hline 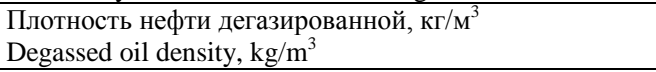 & 815 & 820 & 817 \\
\hline $\begin{array}{l}\text { Начальное пластовое давление, МПа } \\
\text { Initial reservoir pressure, MPa }\end{array}$ & 61,80 & 61,80 & 62,80 \\
\hline $\begin{array}{l}\text { Текущее пластовое давление, МПа } \\
\text { Current reservoir pressure, MPa }\end{array}$ & 58,80 & 59,20 & 60,20 \\
\hline $\begin{array}{l}\text { Вязкость, мПа } \\
\text { Viscosity, mPa·s }\end{array}$ & 0,22 & 0,20 & 0,20 \\
\hline $\begin{array}{l}\text { Газосодержание, кг/ } \mathrm{M}^{3} \\
\text { Gas content, } \mathrm{kg} / \mathrm{m}^{3}\end{array}$ & 417 & 463 & 387 \\
\hline $\begin{array}{l}\text { Давление насыщения, МПа } \\
\text { Saturation pressure, MPa }\end{array}$ & 27,40 & 28,40 & $\begin{array}{c}\text { нет данных } \\
\text { no data }\end{array}$ \\
\hline $\begin{array}{l}\text { Содержание, \% мас. } \\
\text { Сontent, \% wt. } \\
\text { парафина/paraffin } \\
\text { асфальтенов/asphaltenes } \\
\text { смол силикагелевых/silica gel resins } \\
\text { серы/sulfur }\end{array}$ & $\begin{array}{l}2,30 \\
0,17 \\
2,60 \\
0,08 \\
\end{array}$ & $\begin{array}{l}4,55 \\
0,12 \\
1,99 \\
0,09 \\
\end{array}$ & $\begin{array}{c}3,44 \\
0,03 \\
1,86 \\
- \\
\end{array}$ \\
\hline $\begin{array}{l}\text { Средняя глубина кровли в добывающих скважинах, м } \\
\text { Average roof depth in production wells, m }\end{array}$ & $-4328,20$ & $\begin{array}{l}\text { Пласт II /Layer II }-4494,80 \\
\text { Пласт V/Layer V }-4663,70 \\
\end{array}$ & $-4666,40$ \\
\hline $\begin{array}{l}\text { Средняя нефтенасыщенная толщина, м } \\
\text { Average oil-saturated thickness, m }\end{array}$ & 41,50 & 205,00 & 56,40 \\
\hline $\begin{array}{l}\text { Тип залежи } \\
\text { Deposit type }\end{array}$ & \multicolumn{3}{|c|}{$\begin{array}{l}\text { Мacсивно-пластовый, сводовый } \\
\text { Massive-bedded, vaulted }\end{array}$} \\
\hline $\begin{array}{l}\text { Тип коллектора } \\
\text { Reservoir type }\end{array}$ & \multicolumn{3}{|c|}{$\begin{array}{c}\text { Поровый, терригенный, микрокаверново-трещинный } \\
\text { Porous, terrigenous, micro-cavernous-fractured }\end{array}$} \\
\hline
\end{tabular}


Выход светлых углеводородов, выкипающих при температуре до $300{ }^{\circ} \mathrm{C}$ составляет $64 \%$, из них бензиновых фракций до $200{ }^{\circ} \mathrm{C}$ содержится $35 \%$. В пластовых условиях плотность нефти равна 576 кг $/ \mathrm{M}^{3} ;$ вязкость 0,22 МПасс; объемный коэффициент 2,07; давление насыщения 27,4 МПа; газонасыщенность пластовой нефти $417 \mathrm{~m}^{3} / \mathrm{T}$.

Растворенный в нефти газ по углеводородному составу относится к метановым. Этана содержится $14,54 \%$; пропана - 8,30 \%; бутана +изобутана $4,84 \%$; пентана+высшие - 3,36 \%; углекислого газа $1,94 \%$. Относительная плотность газа к воздуху составляет 1,042 . По групповому углеводородному составу нефть альбских отложений относится к типу алкано-циклановых. Содержание алканов составляет от 49 до $89 \%$.

Нефть альб-аптских отложений малосернистая (серы 0,09\% мас.), легкая (плотность 820 кг/м ${ }^{3}$ ), малосмолистая (силикагелевых смол в среднем 1,99 \% мас., асфальтенов 0,12 \% мас.), парафинистая (парафина 4,55\%) (табл. 2). Содержание светлых нефтепродуктов, выкипающих до $300{ }^{\circ} \mathrm{C}$, достигает $61 \%$ об., в том числе бензиновых фракций до $200{ }^{\circ} \mathrm{C}-37 \%$. Плотность нефти в пластовых условиях составляет 596 кг/м ${ }^{3}$; вязкость $0,2 \mathrm{MПасс,} \mathrm{объемный} \mathrm{коэффициент}$ 2,0 ; давление насыщения в среднем 28,4 МПа.

По групповому углеводородному составу нефть альб-аптской залежи относится к алкано-циклановому типу. Бензиновые фракции в основном состоят из алкановых углеводородов (49-92 \% мас.). Растворенный в нефти газ альб-аптской залежи по составу углеводородов является метановым (68,09\% об.). Содержание этана составляет $14,00 \%$ об., пропана $-7,56 \%$, бутана+изобутана $-5,43 \%$, пентана+высших $-1,60 \%$, азота $0,80 \%$ и углекислого газа $-2,52 \%$. Газ не содержит сероводорода и других агрессивных компонентов. Относительная плотность газа к воздуху равна 0,859 (табл. 3 ).

Таблица 3. Компонентный состав и свойства попутного газа

Table 3. Component composition and properties of associated gas

\begin{tabular}{|c|c|c|c|c|c|c|c|c|}
\hline \multirow{2}{*}{$\begin{array}{l}\text { Пласт } \\
\text { Layer }\end{array}$} & \multirow{2}{*}{$\begin{array}{c}\text { Относительная } \\
\text { плотность газа } \\
\text { по воздуху } \\
\text { Relative gas } \\
\text { density in air } \\
\end{array}$} & \multicolumn{7}{|c|}{$\begin{array}{c}\text { Содержание } \\
\text { Content, \% }\end{array}$} \\
\hline & & $\begin{array}{l}\text { Метан } \\
\text { Methane }\end{array}$ & $\begin{array}{c}\text { Этан } \\
\text { Ethane }\end{array}$ & $\begin{array}{l}\text { Пропан } \\
\text { Propane }\end{array}$ & $\begin{array}{c}\text { Бутан + изобутан } \\
\text { Butane + Isobutane }\end{array}$ & $\begin{array}{c}\text { Пентан + высшие } \\
\text { Pentane + higher }\end{array}$ & $\begin{array}{c}\text { Азот } \\
\text { Nitrogen }\end{array}$ & $\mathrm{CO}_{2}$ \\
\hline $\begin{array}{l}\text { Альбский } \\
\text { Albian }\end{array}$ & 1,042 & 66,50 & 14,54 & 8,30 & 4,84 & 3,36 & - & 1,94 \\
\hline $\begin{array}{l}\text { Аптский } \\
\text { Aptian }\end{array}$ & 0,859 & 68,09 & 14,00 & 7,56 & 5,43 & 1,60 & 0,80 & 2,52 \\
\hline $\begin{array}{l}\text { Барремский } \\
\text { Barremian }\end{array}$ & 0,838 & 68,09 & 14,15 & 7,62 & 5,36 & 2,15 & 0,57 & 2,51 \\
\hline
\end{tabular}

Нефть барремской залежи легкая (плотность 817 кг/м ${ }^{3}$ ), бессернистая, малосмолистая (содержание силикагелевых смол 1,86 \%; асфальтенов 0,03 \% мас.); парафинистая (парафина 3,44 \%). Светлые фракции в нефти содержатся в количестве $61 \%$ об., в том числе бензиновых до $200{ }^{\circ} \mathrm{C}-35,5 \%$ (табл. 2).

\section{Анализ методов интенсификации}

Работа скважин и скважинного оборудования в условиях эксплуатации меловых отложений Горячеисточненского месторождения осложняется асфальтосмолистыми и парафинистыми отложениями (АСПО) $[8,9]$. В период, предшествующий военным событиям, основным средством для удаления АСПО в насосно-компрессорных трубах и призабойной зоне пласта (ПЗП) являлись растворители бутилбензольной фракции (ББФР) и бутил-толуоловой фракции (БТФР) или их смесь со стабильным газовым бензином.

После военных событий на нефтяных месторождениях для удаления АСПО в лифтовых трубах применялись различные способы по обработке призабойной зоны пласта нефтедобываюших скважин, в том числе закачка в пласт соляной кислоты $[10,11]$. Этот способ обеспечивает значительное увеличение проницаемости в призабойной пластовой зоне, но его эффективность невысока из-за вторичной кольматации ПЗП продуктами реакции.
Изучены и рассмотрены современные процессы интенсификации добычи нефти, а также условия, при которых образуются или разрушаются сложные отложения [12-18]. В результате изысканий эффективных технологий был отмечен опыт применения метода обработки призабойной пластовой зоны скважины, состоящий из двух этапов. На первом этапе производят закачку раствора кислоты в продуктивный нефтяной пласт. На втором этапе проводят технологическую выдержку и затем извлекают отработанный химический реагент созданием депрессии [19]. Такой способ обеспечивает возможность за счет депрессионного воздействия извлечь продукты реакции из скважины и, тем самым, предотвратить возникновение вторичной кольматации призабойной пластовой зоны, но эффективность данного способа невысокая.

Известен способ обработки призабойной зоны скважины [20], применение которого оказывает значительное влияние на процессы вторичной кольматации ПЗП. Он нашел достаточно широкое применение на месторождениях Республики Татарстан. Для его осуществления производят целый ряд операций. Сначала в зону продуктивного пласта продавливают раствор кислоты, затем производят технологическую выдержку и последующее депрессионное воздействие, далее водным раствором эмульгатора осуществляют глушение скважины и продавливание легкой нефтью раствора кислоты в призабойную зону. После прове- 
денных операций следует трехчасовая технологическая выдержка, затем свабированием выполняют депрессионное воздействие до тех пор, пока водородный показатель $\mathrm{pH}$ не достигнет значений в пределах от 6 до 7, и только потом в скважину устанавливается насосное оборудование и производится освоение. Этот способ эффективен, но предполагает большие затраты времени и средств. Также проводились обработки ПЗП с помощью органических растворителей, но для достижения положительного эффекта требовалось проведение порядка 30 обработок.

На современном этапе борьбу с АСПО в насоснокомпрессорных трубах и призабойной зоне предлагается осуществлять путём закачки органического растворителя фирмы «РИНГО».

Анализ динамики давления в лифтовых трубах и выкидных линиях скважин, прирост дебита скважины до и после обработки указывает на эффективность применения растворителей этого типа для удаления АСПО.

Обработку терригенных нижнемеловых коллекторов проводили составом органического растворителя марки РИНГО-ГКС. Этот состав представляет собой композицию, выполненную на основе смеси плавиковой, хлоркарбоновой, соляной кислот с модифицирующими добавками. В качестве модифицирующих добавок используются ингибиторы цементного камня и кислотной коррозии металла, реагенты пролонгированного глинокислотного воздействия на скелет горной породы-коллектора и кольматанты, высокоактивные поверхностно-активные вещества (ПАВ) синергетического действия, ингибиторы выпадения твердого осадка из отработанного раствора, бактерициды. Удельный объем кислот составляет для ГКС $0,08 \ldots 0,55 \mathrm{~m}^{3} / \mathrm{M} \mathrm{H}_{\text {нн }}$.

Также для обработки призабойной зоны пласта терригенных коллекторов использовали органические растворители марки «РИНГО-СКС» и МКС. Эти растворители представляют собой композицию на основе смеси монохлоруксусной, хлоркарбоновой, соляной кислот и модифицирующих добавок. В качестве при-

\section{СПИСОК ЛИТЕРАТУРЫ}

1. Николаев Н.И., Шипулин А.В., Купавых К.С. Результаты исследований и эффективность применения комплексной технологии химической обработки призабойной зоны пласта // Территория Нефтегаз. - 2015. - № 2. - С. 79-83.

2. Омельянюк М.В., Рогозин А.А., Леонов Я.А. Интенсификация добычи нефти для терригенных коллекторов с применением кислотных композиций // Булатовские чтения. - Краснодар, 2018. - T. 2-2. - C. 59-62.

3. Щелкачев В.Н. Разработка нефтеводоносных пластов при упругом режиме. - М.: Гостоптехиздат, 1959. - 467 с

4. Керимов И.А. Старогрозненское месторождение: добыча нефти и газа и сейсмическая активность // International Conference on Innovations and Prospects of Development of Mining Machinery and Electrical Engineering, IPDME 2018. Transportation of Mineral Resources. - Санкт-Петербург, 2018. $072004 \mathrm{c}$

5. Керимов И.А., Эзирбаев Т.Б., Эльжаев А.С. Анализ методик выделения коллекторов в альб-аптских отложениях терскосунженской нефтегазоносной области // Геология и геофизика Юга России. - 2019. - Т. 9. - № 4. - С. 28-37.

6. Эзирбаев Т.Б. Выделение терригенных коллекторов в альбаптских отложениях Терско-сунженской нефтегазоносной об- садок используют ингибиторы цементного камня и кислотной коррозии метала, реагенты пролонгированного кислотного воздействия на скелет горной породы, высокоактивные ПАВ синергетического действия, ингибиторы выпадения твердого осадка из отработанного раствора, бактерициды. Кислотные составы подбираются для конкретных геолого-физических условий разработки залежей пласта. Удельный объем кислот СКС и МКС составил $0,15 \ldots 0,33 \mathrm{~m}^{3} / \mathrm{M} \mathrm{H}_{\mathrm{Hн}}$.

В соответствии с полученными экспериментальными данными по добыче нефти показатели дебита кратно превышают потенциал скважин, рассчитанный по техническому режиму при проведении интенсификации добычи нефти.

Это позволяет говорить об эффективности проведенной очистки призабойной зоны скважины от кольматанта и о существенном увеличении ее радиуса действия, как результата растворения горной породы в пристволовой зоне.

\section{Заключение}

В процессе эксплуатации нефтедобывающих скважин в призабойной зоне пласта наблюдается активное отложение кольматирующих элементов, значительно сокращающих проницаемость призабойной пластовой зоны и, как следствие, снижающих продуктивность нефтедобывающих скважин. Традиционно применяемая технология обработки призабойной зоны пласта растворами кислот не дает желаемого эффекта. Более совершенные технологии, сочетающие солянокислотную обработку и депрессионное воздействие, к сожалению, имеют невысокую эффективность и успешность.

С целью интенсификации добычи и увеличения нефтеотдачи пласта предлагается производить обработку терригенных коллекторов нижнего мела органическими растворителями РИНГО-ГКС, РИНГОСКС и МКС.

Экспериментальные обработки в скважине показали эффективность воздействия на призабойную зону и полную очистку от кольматирующих отложений.

ласти на основе технологии интерпретации данных каротажа ТАВC // Современные проблемы геологии, геофизики и геоэкологии Северного Кавказа. - Грозный: ГГНТУ, 2019. С. 524-527.

7. РД 153-39.0-110-01. Методические указания по геологопромысловому анализу разработки нефтяных и нефтегазовых месторождений. - М.: ФГУ «Экспертнефтегаз» Министерства энергетики Российской Федерации, 2002. - 89 с.

8. Булчаев Н.Д. Разработка и исследование технологий и технических средств для поддержания пластового давления нефтяных месторождений: автореф. дис.... канд. техн. наук. - Тюмень, 2013. - 23 с

9. Васильев С.И., Милосердов Е.Е., Булчаев Н.Д. Проблемы эксплуатации нефтяных и газовых скважин // Горная промышленность. - 2015. - № 3 (121). - С. 86-88.

10. Паникаровский Е.В. Обработка призабойной зоны низкопроницаемых терригенных пластов на многопластовых нефтегазоконденсатных месторождениях // Известия высших учебных заведений. Нефть и газ. - 2014. - № 2. - С. 43-47.

11. An overview of chemical enhanced oil recovery: recent advances and prospects / A.O. Gbadamosi, R. Junin, M.A. Manan, A. Agi, A.S. Yusuff // International Nano Letters. - 2019. - № 9. P. 171-202. 
12. A dual-well system and thermal-gas-chemical formation treatment: combined methods for high-viscosity oil production / I. Ali, S.I. Gubanov, K.A. Ovchinnikov, V.A. Olkhovskaya, G.A. Kovaleva, E. Galunin, A. Tkachev // Journal of Petroleum Science and Engineering. - 2020. - T. 194. - P. 107554. DOI: $10.1016 /$ j.petrol.2020.

13. Blasting methods for intensification of oil and gas recovery, experience of their use in the Ukraine and Russian deposits / Yu.I. Voitenko, N.A. Lysyuk, V.I. Krasko, L.A. Mityuk // Journal of Mining Science. - 2002. - V. 38. - № 2. - P. 161-167. DOI: 10.1023/A:1021115622187

14. Experimental stady of structural-mechanical properties of heavy oil / R. Bayamirova, A. Togasheva, A. Zholbassarova, Z. Islamberdiyev, M. Bissengaliev, D. Suierov // Studia Universitatis Babes-Bolyai Chemia. - 2020. - V. 65. - № 1. P. 233-244. DOI: 10.24193/subbchem.2020.1.18

15. Innovative water-blocking agent based on high stable emulsion with nanoparticles for IOR implementation / V. Sergeev, I. Kim, J. Zeigman, R. Yakubov // Society of Petroleum Engineers - Abu Dhabi International Petroleum Exhibition and Conference 2018. Abu Dhabi, ADIPEC, 2018. - 11 p. DOI: 10.2118/192742-MS
16. Sergeev V., Tanimoto K., Abe M. The water-blocking agent with improved properties for IOR implementation // IOR 2019 - 20th European Symposium on Improved Oil Recovery. - Pau, France, 2019. - P. 1-11. DOI:10.3997/2214-4609.201900162

17. Recent advances in nanoparticles enhanced oil recovery: rheology, interfacial tension, oil recovery, and wettability alteration M.S. Kamal, A.A. Adewunmi, A.S. Sultan, M.F. Al-Hamad, U. Mehmood // Journal of Nanomaterials. - 2017. - V. 2017. P. 2473175.

18. Enhanced oil recovery and in situ upgrading of heavy oil by supercritical water injection / Q. Zhao, L. Guo, Y. Wang, H. Jin, L. Chen, Z. Huang // Energy and Fuels. - 2020. - V. 34. - № 1. P. 360-367.

19. Способ обработки призабойной зоны нефтяного пласта: пат. Рос. Федерация, № $2140531 \mathrm{C1}$, заявл. 12.08.1998; опубл. 27.10.1999. - $10 \mathrm{c}$

20. Способ обработки призабойной зоны скважины: пат. Рос Федерация № 2268360 C1, заявл. 10.0.2005; опубл. 20.01.2006. Бюл. № 02. -5 c.

Поступила 01.03.2021 г.

\section{Информация об авторах}

Бакраев М.M., кандидат технических наук, начальник отдела практик и трудоустройства Грозненского государственного нефтяного технического университета им. академика М.Д. Миллионщикова.

Булюкова Ф.3., кандидат технических наук, доцент кафедры машин и оборудования нефтегазовых промыслов Уфимского государственного нефтяного технического университета.

Думлер E.Б., кандидат технических наук, доцент кафедры машин и оборудования нефтегазовых промыслов Уфимский государственный нефтяного технического университета.

Дельбиев А.C., аспирант Грозненского государственного нефтяного технического университета им. академика М.Д. Миллионщикова. 
UDC 622.276 .6

\title{
RESEARCH OF METHODS FOR INTENSIFICATION OF OIL PRODUCTION FROM LOWER CRETACEOUS SEDIMENTS OF GORYACHEISTOCHNENSKOE FIELD
}

\author{
Mubarik M. Bakraev1, \\ mubarik@yandex.ru
}

Flyura Z. Bulyukova², flura2003@mail.ru

Elena B. Dumler², dumler08@mail.ru

\author{
Ayndi S. Delbiev 1 , \\ Ayndi.delbiev@mail.ru \\ 1 Grozny State Oil Technical University, \\ 100, H.A. Isayev avenue, Grozny, 364902, Russia. \\ 2 Ufa State Oil Technical University, \\ 1, Cosmonavtov street, Ufa, 450062, Russia.
}

\begin{abstract}
At the present stage, the oil industry faces serious challenges in finding new effective technologies to enhance oil recovery. During the development of the Lower Cretaceous oil deposits, there is a tendency for significant decrease in well production due to deposits in the tubing of sparingly soluble asphaltene-resinous substances. With a drop in flow rate, pressure and temperature, the intensity of deposits, including bridging elements in the bottom-hole formation zone, increased. The article solves the problem of selecting an effective method for treating the bottom-hole zone in order to increase the intensification of production and increase the oil production of the formation and due to a more complete cleaning from hard-to-remove clogging deposits.

The main aim of the study is to determine the most effective way of treating terrigenous reservoirs of the Lower Cretaceous deposits to influence the skeleton of the rock forming the reservoir and protect it from clogging deposits.

Object: Goryacheistochnenskoe field located at the eastern end of the Tersk ridge, Grozny region of the Chechen Republic. The field is multi-layer. The Miocene, Upper Cretaceous, Albian, Alb-Aptian and Barremian deposits were in development and exploitation. The largest objects are associated with the Upper Cretaceous and Alb-Aptian deposits of the Lower Cretaceous. The Miocene deposit is practically depleted. The Albskaya and Barremskaya deposits are underexplored and are operated by single wells. Productive deposits of the AlbAptian deposit are characterized by relatively low reservoir properties.

Methods: study of various technological methods of impact on the bottom-hole zone of the well.

Results. In order to intensify and increase oil production, it is proposed to treat the Lower Cretaceous terrigenous reservoirs with organic solvents RINGO-GKS, RINGO-SKS and MKS. Experimental treatments in wells have shown the effectiveness of impact on the bottomhole zone and its complete cleaning from clogging deposits.
\end{abstract}

\section{Key words:}

Oil production intensification, asphalt-resinous paraffin deposits, bridging elements, Lower Cretaceous formation, bottom-hole formation zone.

\section{REFERENCES}

1. Nikolaev N.I., Shipulin A.V., Kupavykh K.S. Research results and the effectiveness of the integrated technology of chemical treatment of the bottomhole formation zone. Territory Neftegaz, 2015, no. 2, pp. 79-83. In Rus.

2. Omelyanyuk M.V., Rogozin A.A., Leonov Ya.A. Intensifikatsiya dobychi nefti dlya terrigennykh kollektorov s primeneniem kislotnykh kompozitsiy [Stimulation of oil production for terrigenous reservoirs using acid compositions]. Bulatovskie chteniya [Bulatovskie readings]. Krasnodar, 2018. Vol. 2-2, pp. 59-62.

3. Shchelkachev V.N. Razrabotka neftevodonosnykh plastov pri uprugom rezhime [Development of oil-bearing reservoirs under elastic conditions]. Moscow, Gostoptekhizdat Publ., 1959. 467 p.

4. Kerimov I.A. Starogroznenskoe mestorozhdenie: dobycha nefti gaza i seysmicheskaya aktivnost [Starogroznenskoe field: oil and gas production and seismic activity]. IOP Conference Series: Earth and Environmental Science International Conference on Innovations and Prospects of Development of Mining Machinery and Electrical Engineering, IPDME 2018 - Transportation of Mineral Resources. Saint-Peterburg, 2018. pp. 072004.

5. Kerimov I.A., Ezirbaev T.B., Elzhaev A.S. Analysis of methods for identifying reservoirs in the Albian-Aptian sediments of the Tersko-Sunzha oil and gas region. Geology and geophysics of the South of Russia, 2019, vol. 9, no. 4, pp. 28-37. In Rus.
6. Ezirbaev T.B. Vydelenie terrigennykh kollektorov $\mathrm{v}$ alb-aptskikh otlozheniyakh tersko-sunzhenskoy neftegazonosnoy oblasti na osnove tekhnologii interpretatsii dannykh karotazha TAVS [Identification of terrigenous reservoirs in the Albian-Aptian sediments of the Tersko-Sunzha oil and gas region based on the technology of interpretation of logging data TAVS]. Sovremennye problemy geologii, geofiziki i geoekologii [Modern problems of geology, geophysics and geoecology of the North Caucasus]. Grozny, GGNTU Publ., 2019. pp. 524-527.

7. RD 153-39.0-110-01. Metodicheskie ukazaniya po geologopromyslovomu analizu razrabotki neftyanykh i neftegazovykh mestorozhdeniy [RD 153-39. 0-110-01. Guidelines for geological and field analysis of oil and gas fields development]. Moscow, Expertneftegaz Publ., 2002. 89 p.

8. Bulchaev N.D. Razrabotka $i$ issledovanie tekhnologiy $i$ tekhnicheskikh sredstv dlya podderzhaniya plastovogo davleniya neftyanykh mestorozhdeniy. Avtoreferat Dis. Kand. nauk [Development and research of technologies and technical means for maintaining reservoir pressure of oil fields. Cand. Diss. Abstract]. Tyumen, 2013. $23 \mathrm{p}$

9. Vasiliev S.I., Miloserdov E.E., Bulchaev N.D. Problems of exploitation of oil and gas wells. Mining industry, 2015, no. 3 (121), pp. 86-88.

10. Panikarovsky E.V. Treatment of the bottomhole zone of lowpermeability terrigenous formations in multilayer oil and gas con- 
densate fields. Izvestia of higher educational institutions. Oil and gas, 2014, no. 2, pp. 43-47. In Rus.

11. Gbadamosi A.O., Junin R., Manan M.A., Agi A., Yusuff A.S. An overview of chemical enhanced oil recovery: recent advances and prospects. International Nano Letters, 2019, no. 9, pp. 171-202.

12. Ali I., Gubanov S.I., Ovchinnikov K.A., Olkhovskaya V.A., Kovaleva G.A., Galunin E., Tkachev A. A dual-well system and thermal-gas-chemical formation treatment: combined methods for high-viscosity oil production. Journal of Petroleum Science and Engineering, 2020, vol. 194, pp. 107554

13. Voitenko Yu.I., Lysyuk N.A., Krasko V.I., Mityuk L.A. Blasting methods for intensification of oil and gas recovery, experience of their use in the Ukraine and Russian deposits. Journal of Mining Science, 2002, vol. 38, no. 2, pp. 161-167. DOI: 10.1023/A:1021115622187

14. Bayamirova R., Togasheva A., Zholbassarova A., Islamberdiyev Z., Bissengaliev M., Suierov D. Experimental stady of structuralmechanical properties of heavy oil. Studia Universitatis BabesBolyai Chemia, 2020, vol. 65, no. 1, pp. 233-244. DOI: $10.24193 /$ subbchem.2020.1.18

15. Sergeev V., Kim I., Zeigman J., Yakubov R. Innovative waterblocking agent based on high stable emulsion with nanoparticles for ior implementation. Society of Petroleum Engineers - Abu
Dhabi International Petroleum Exhibition and Conference 2018. Abu Dhabi, ADIPEC, 2018. 11 p. DOI: 10.2118/192742-MS

16. Sergeev V., Tanimoto K., Abe M. The water-blocking agent with improved properties for ior implementation. IOR $2019-20^{\text {th }} \mathrm{Eu}$ ropean Symposium on Improved Oil Recovery. Pau, France, 2019. pp. 1-11. DOI: 10.3997/2214-4609.201900162

17. Kamal M.S., Adewunmi A.A., Sultan A.S., Al-Hamad M.F., Mehmood U. Recent advances in nanoparticles enhanced oil recovery: rheology, interfacial tension, oil recovery, and wettability alteration. Journal of Nanomaterials, 2017, vol. 2017, pp. 2473175

18. Zhao Q., Guo L., Wang Y., Jin H., Chen L., Huang Z. Enhanced oil recovery and in situ upgrading of heavy oil by supercritical water injection. Energy and Fuels, 2020, vol. 34, no. 1, pp. 360-367.

19. Baranov Yu.V., Ziyatdinov I.Kh., Medvedev N.Ya., Muslimov R.Kh., Nigmatullin I.G., Prokoshev N.A., Shemetillo V.G. Sposob obrabotki prizaboynoy zony neftyanogo plasta [Method of processing the bottom-hole zone of an oil reservoir]. Patent RF, no. $2140531 \mathrm{C} 1,1999$

20. Ibragimov N.G., Sharikov G.N., Kormishin E.G., Chupikova I.Z., Torikova L.I., Ryskina N.Z. Sposob obrabotki prizaboynoy zony skvazhiny [Method of processing the bottom-hole zone of the well]. Patent RF, no. 2268360 C1, 2006.

Received: 1 March 2021.

Information about the authors

Mubarik M. Bakraev, Cand Sc., associate professor, Grozny State Oil Technical University.

Flyura Z. Bulyukova, Cand Sc., associate professor, Ufa State Oil Technical University.

Elena B. Dumler, Cand Sc., associate professor, Ufa State Oil Technical University.

Ayndi S. Delbiev, graduate student, Grozny State Oil Technical University. 